\title{
Dynamic characteristics of soil properties in a Robinia pseudoacacia vegetation and coastal eco-restoration
}

\author{
Peili Mao ${ }^{\mathrm{a}}$, Hongxiang $\mathrm{Mu}^{\mathrm{b}}$, Banghua Cao ${ }^{\mathrm{a}, * *}$, Yongjian Qin $^{\mathrm{c}}$, Hongbo Shao ${ }^{\mathrm{d}, \mathrm{e}, *}$, \\ Shumei Wang ${ }^{\mathrm{a}}$, Xiuguo Tai ${ }^{\mathrm{a}}$ \\ a Key Laboratory of Agricultural Ecology and Environment, Shandong Agricultural University, Taian 271018, China \\ ${ }^{\mathrm{b}}$ College of Forestry. Agricultural University of Hebei, Baoding 071000, China \\ c Shandong Forest Tree Seedling Station, Jinan 250014, China \\ ${ }^{\mathrm{d}}$ Institute of Agro-biotechnology, Jiangsu Academy of Agricultural Sciences, Nanjing 210014, China \\ e Yantai Institute of Coastal Zone Research, Chinese Academy of Sciences, Yantai 264003, China
}

\section{A R T I C L E I N F O}

\section{Article history:}

Received 2 December 2015

Received in revised form 17 February 2016

Accepted 21 March 2016

Available online 8 April 2016

\section{Keywords:}

Coastal saline-alkali soil

Robinia pseudoacacia

Precipitation

Costal eco-restoration

\begin{abstract}
A B S T R A C T
Precipitation is one of the major determinants of soil moisture in plantations growing in the saline-alkali soil in the Yellow River Delta. The present study was conducted on a 28-yr old Robinia pseudoacacia plantation, a major vegetation type of the Yellow River Delta, and the results indicated strong seasonal patterns in soil moisture, salt, nutrient and enzyme activities at varying depths with respect to annual precipitation. Soil moisture during the growing season of March to October fluctuated drastically in response to precipitation events and was generally higher than that from November to February. Furthermore, soil water content in the $0-60 \mathrm{~cm}$ soil layer was positively correlated with precipitation during the same period but not for the value in the $60-80 \mathrm{~cm}$ soil layer. Salt content in different soil layers increased gradually from November to February, decreased from February to September and then increased in October. Precipitation was strongly and negatively correlated with soil salt content in different soil layers (except $20-40 \mathrm{~cm}$ ). Soil enzymes became less active and soil nutrient contents decreased with soil depth, though different enzymes and nutrients showed seasonal variations. The activity of polyphenol oxidase increased in spring, reached the maximum values in June, and decreased in later months. The activity of alkaline phosphatase, proteinase and urease fluctuated throughout the growing season, with the maximum values in October. Available phosphorous increased in the early months and decreased after August, whereas available potassium, hydrolysable nitrogen and organic substances content in soil gradually increased throughout. Therefore, it is suggested that precipitation is the crucial limiting factor to tree growth through impacts on soil moisture, salt, nutrient and enzyme activities in saline-alkali soils in the Yellow River Delta.
\end{abstract}

(c) 2016 Elsevier B.V. All rights reserved.

\section{Introduction}

The Yellow River Delta is one of the most representative estuary wetland ecosystems with active land-ocean interactions in the world. Robinia pseudoacacia plantation started in the 1970s and 1980 s in the maximum area arbor forest, exerting notably ecological function in this region. However, started from 1990, $R$. pseudoacacia plantation gradually showed the withering tree top

\footnotetext{
* Corresponding author at: Yantai Institute of Coastal Zone Research, Chinese Academy of Sciences, Yantai 264003, China.

** Corresponding author.

E-mail addresses: caobanghua@126.com (B. Cao), shaohongbochu@126.com (H. Shao).
}

and even the sheet death. Many researchers have studied canopy health (Liu et al., 2008), soil water storage ability (Xia et al., 2009) and soil physico-chemical properties (Zhang and Xing, 2009; Sun et al., 2006) on this forest. Precipitation is one of the major determinants of soil moisture in plantations growing in this area. However, it is still unclear the impacts of precipitation on dynamic characteristics of soil properties in the R. pseudoacacia plantation.

Soil characteristics have a vital impact on the ecosystem restoration (Toktar et al., 2016). Soil enzymes are the main mediators of soil biological processes because of their intimate relationship to organic matter degradation, mineralization and nutrient cycling (Marx et al., 2001). For example, polyphenol oxidase plays a role in the process of conversion of aromatic organic compounds to humus in soil. Catalase enhances oxidization of compounds using $\mathrm{H}_{2} \mathrm{O}_{2}$ in soil. Phosphatase hydrolyzes compounds of organic phosphorus 
and transforms them into inorganic forms for plants. Proteases are mainly responsible for hydrolyzing soil proteins into peptides and amion acids. Urease catalyses the hydrolysis of organic nitrogen to inorganic forms, which is from urea-type substrates to ammonia or ammonium ion. Invertase catalyses the hydrolysis of sucrose to glucose and fructose, and is linked to the soil microbial biomass.

Soil enzymes are produced by plants, animals and microorganisms (Zornoza et al., 2006). Their activities have been proposed as appropriate indicators of soil quality due to their high sensitivity to disturbance (Zornoza et al., 2006; García-Ruiz et al., 2008; Hendriksen et al., 2015). Soil moisture is an important determinant factor for soil enzyme activities (Henry, 2013). With the increase of soil moisture, enzyme potential activities increase (Baldrian et al., 2013; ÁBear et al., 2014). Whereas, Acosta-Martinez et al. (2011) reported high enzyme activities in drought soil. This can be explained with the report that under waterlogging condition, enzyme activities were impeded (Kang and Freeman, 1999). Variations on precipitation have been suggested to possess significant effects on enzyme activities (Munson et al., 2010; Ladwig et al., 2015). Salinity also has a powerful influence on soil enzyme activities. The increase of salinity decreases soil enzyme activities (Saviozzi et al., 2011; Pan et al., 2013). On the contrary, Morrissey et al. (2014) found salinity increase enhanced enzyme activity due to the increase of bacterial abundance in tidal wetlands. However, not all enzymes were sensitive to salinity (Saviozzi et al., 2011; Pan et al., 2013). Soil nutrients are positively correlated with enzyme activity (Pan et al., 2013; Burke et al., 2011), such as soil organic matter (García-Ruiz et al., 2008; Hendriksen et al., 2015). However, few studies were carried out to explore the impact of precipitation on soil moisture, salt, nutrient and enzyme in the coastal salinealkali soil.

Soil salinity and water are two dominant factors on plant distribution in the Yellow River Delta (Yu et al., 2012). This area suffers greatly from soil secondary salinization and insufficient precipitation, demonstrating a high evaporation-precipitation ratio. Moreover, the decreases of freshwater supply from the yellow river in recent decades and intense human activities have significantly changed the original conditions in this area (Cui et al., 2010). Therefore, the main fresh water source of the coastal saline-alkali soil is from the precipitation and it determines the $R$. pseudoacacia forest survival and growth in this area. As the productivity decline of the $R$. pseudoacacia forest arose in recent decades, its protective functions have dropped significantly. To elucidate the decline mechanism of $R$. pseudoacacia plantation and recover its ecological functions in the Yellow River Delta, the study objectives were designed to explore soil moisture, salt, nutrient and enzyme seasonal change and examine the interactions among them and the impact of rainfall on them.

\section{Materials and methods}

\subsection{Study area}

The Yellow River Delta is the youngest land in China, which is located at the entrance of the Yellow River to the Bohai Sea. The secondary salinization is severe because of shallow groundwater, high total dissolved solid and sea water intrusion. The study was conducted at the Production base of Jinan Military Region in the Yellow River Delta $\left(37^{\circ} 49^{\prime} 36.4^{\prime \prime} \mathrm{N}, 118^{\circ} 46^{\prime} 37.1^{\prime \prime} \mathrm{E}\right)$. The experimental site has a typical monsoon climate. The annual mean temperature is $12.3^{\circ} \mathrm{C}$, and the minimal and maximum temperature varied from $-23.3^{\circ} \mathrm{C}$ to $41.9^{\circ} \mathrm{C}$. The frost-free period is 210 days with an effective accumulated temperature of about $4300^{\circ} \mathrm{C}$. The average annual precipitation is $555.9 \mathrm{~mm}$, with nearly $70 \%$ of the precipitation falling in summer (June to August). The average annual evapora- tion is $1962 \mathrm{~mm}$, and $51.7 \%$ of annual evaporation occurs in the spring. Saline soil are the dominate soil types in the study area. Soil salt content range is $1.0 \%$ - $2.6 \%$ and $\mathrm{pH}$ range is $6.79-8.87$. Groundwater level is approximately $1.5 \mathrm{~m}$. The main vegetation in the delta includes Phragmites australis, Suaeda salsa and Tamarix chinensis. The experimental forest is pure $R$. pseudoacacia tree which was established in 1980 s by planting nursery-raised one year old seedlings at a spacing of $2.5 \mathrm{~m} \times 3 \mathrm{~m}$. At present, the preservation rate of this plantation is $78 \%$.

\subsection{Experimental design}

Three plots were established at typical pure $R$. pseudoacacia forest. The size of the sample plots was $30 \mathrm{~m} \times 30 \mathrm{~m}$. Six soil samples were collected randomly from each plot using a soil core cutter (diameter, $7.5 \mathrm{~cm}$ ) for $0-80 \mathrm{~cm}$ soil depth at $20 \mathrm{~cm}$ intervals. Soil water content and salt content in different depths were monitored every month from November of 2007 to October of 2008. Furthermore, six soil samples of $R$. pseudoacacia forest in each plot were collected separately using soil core cutter from 0 to $20 \mathrm{~cm}$ and $20-40 \mathrm{~cm}$ in April, June, August and October of 2008. The soil samples of the same depth were mixed. The soil samples were placed in sealed plastic bags and taken to the laboratory. Some fresh soil samples were preserved at $4{ }^{\circ} \mathrm{C}$ for measurement of enzyme activity. Another portion was used for soil parameter analyses.

\subsection{Soil moisture, salinity, enzyme and nutrient analysis}

Soil moisture was determined gravimetrically by weighing and drying in an oven at $105^{\circ} \mathrm{C}$ for $12 \mathrm{~h}$. Some soil samples was air-dried and used for determining soil electrical conductivity (EC). EC was measured using a conducting meter (DDSJ-308, Shanghai, China) in a 1:5 soil-water extract. A portion of soil samples was air-dried and sieved to $0.25 \mathrm{~mm}$ to measure available phosphorus, available potassium, hydrolysis nitrogen and organic matter.

Soil enzyme activities were measured as described by Guan. All enzyme activities were determined from wet samples. The polyphenol oxidase activity was measured by gallnut method. The catalase activity was measured by potassium permanganate titration method. The alkaline phosphatase activity was expressed on a soil dry weight by correcting for water content in the soil at the time the sample was removed from the incubation bottle and is given in units of $\mathrm{mg} p$-nitrophenol produced $\mathrm{g}^{-1}$ soil $^{-1}$. The protease activity was measured by the method that gelatin was turned into glycin in phosphate buffer $(\mathrm{pH}=7.4)$. The urease activity was determined by the method that urea was turned into $\mathrm{NH}_{3}$ in citric acid buffer $(\mathrm{pH}=6.7)$. The invertase activity was measured by the methods for the formation of glucose by sucrose hydrolysis.

Soil organic matter was measured by the $\mathrm{K}_{2} \mathrm{Cr}_{2} \mathrm{O}_{7}-\mathrm{H}_{2} \mathrm{SO}_{4}$ oxidation method of Walkey and Black. Hydrolysis nitrogen was measured by the alkaline diffusion method, and available phosphorus was measured by the Bray method (Institute of Soil Science, Chinese Academy of Sciences, 1978). Available potassium was measured by flame photometry method (Worth, 1985). Precipitation data was provided by Hekou district meteorological station of Shandong Province, China.

\subsection{Data analysis}

Soil water content, salt content, enzyme activities and nutrient were tested by using a two-way ANOVA. Least-significant difference (LSD) multiple comparisons were conducted. Correlation analyses were used to investigate relationships between precipitation and soil water content and salt content. The statistically 


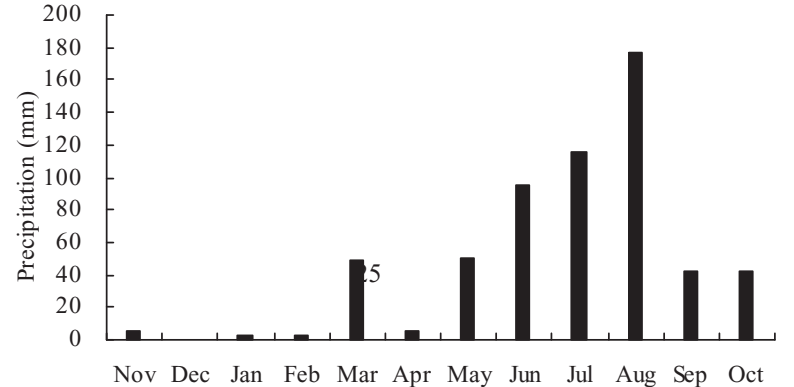

Fig. 1. Precipitation of different months from November 2007 to October 2008.

Table 1

Correlation analysis on precipitation and soil water content in the same time.

\begin{tabular}{llllll}
\hline & Precipitation & $0-20 \mathrm{~cm}$ & $20-40 \mathrm{~cm}$ & $40-60 \mathrm{~cm}$ & $60-80 \mathrm{~cm}$ \\
\hline Precipitation & 1 & $0.701^{*}$ & $0.620^{*}$ & $0.593^{*}$ & $0.496^{\mathrm{a}}$ \\
$0-20 \mathrm{~cm}$ & $0.701^{*}$ & 1 & $0.816^{* *}$ & $0.522^{\mathrm{a}}$ & $0.567^{\mathrm{a}}$ \\
$20-40 \mathrm{~cm}$ & $0.620^{*}$ & $0.816^{* *}$ & 1 & $0.818^{* *}$ & $0.871^{* *}$ \\
$40-60 \mathrm{~cm}$ & $0.593^{*}$ & $0.522^{\mathrm{a}}$ & $0.818^{* *}$ & 1 & $0.842^{* *}$ \\
$60-80 \mathrm{~cm}$ & $0.496^{\mathrm{a}}$ & $0.567^{\mathrm{a}}$ & $0.871^{* *}$ & $0.842^{* *}$ & 1 \\
\hline
\end{tabular}

* Significant at the $<0.05$ probability levels.

** Significant at the $<0.01$ probability levels.

a NS-non-significant at $\mathrm{p}<0.05$.

significant level was set at $\mathrm{P}<0.05$. All statistics were conducted with SPSS for Windows 13.0 (SPSS, Chicago, IL, USA).

\section{Results}

\subsection{Precipitation in study area}

The total precipitation in study area was $587.8 \mathrm{~mm}$ from November 2007 to October 2008. From March to August (except April), the precipitation increased gradually, reaching the maximum in August, and then decreased (Fig. 1). Nearly 66\% of the precipitation fell between June and August. Almost no precipitation occurred from November 2007 to April 2008 (except March). Consequently, drought in the spring (January-April) and main rainfall in the summer (June-August) were the marked rainfall characteristics in the study area.

\subsection{Soil water content of the R. pseudoacacia forest}

Soil depth showed significant effects on soil water content $(\mathrm{F}=7.74, \mathrm{P}<0.01)$. Water content in the $0-20 \mathrm{~cm}$ soil layer was similar to that in $20-40 \mathrm{~cm}$ and $40-60 \mathrm{~cm}$ soil layer $(\mathrm{P}>0.05)$, and they were significantly higher than in $60-80 \mathrm{~cm}$ soil layer $(\mathrm{P}<0.01)$. Precipitation was significantly related with the water content in the $0-20 \mathrm{~cm}, 20-40 \mathrm{~cm}$ and $40-60 \mathrm{~cm}$ soil layer, and showed no significant correlation with the water content in the $60-80 \mathrm{~cm}$ soil layer (Table 1). Therefore, the soil depth of precipitation could effects water content at no more than $60 \mathrm{~cm}$ of soil depth. There were significant differences in soil water content among each month. Soil water content in November, December, January and February were low and showed no significant differences among them $(P>0.05)$. Starting from March soil water content increased, reaching the maximum in July and August, and then declined in September and October (Fig. 2). The interaction between soil depth and month was significant $(F=17.38, P<0.01)$. The maximum soil water content was in March for the $0-20 \mathrm{~cm}$ soil layer, and in July and August for in the $20-40 \mathrm{~cm}$ and $40-60 \mathrm{~cm}$ and in October for the $60-80 \mathrm{~cm}$.

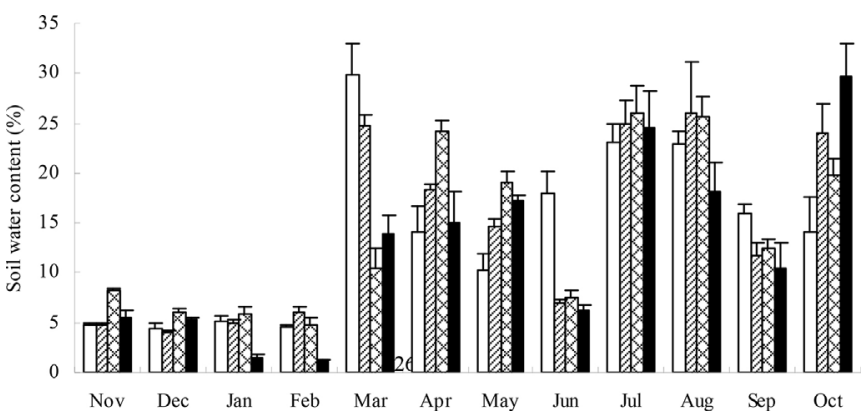

Fig. 2. The dynamic changes of soil water content (\%) of Robinia pseudoacacia forest.

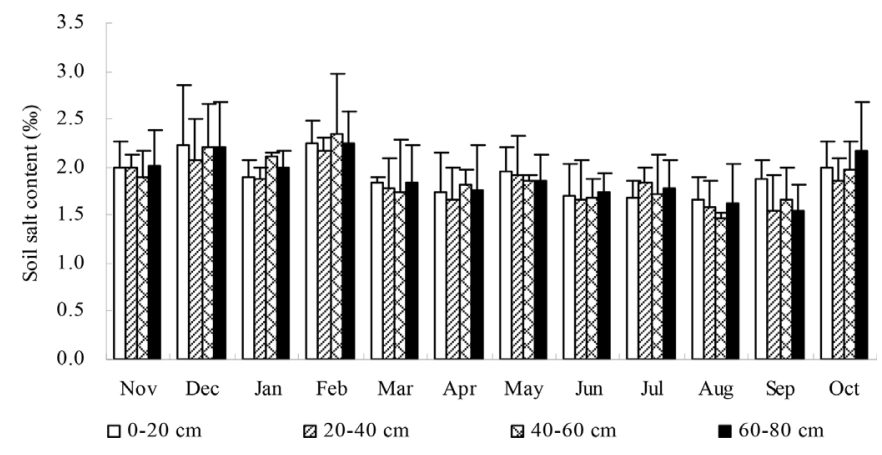

Fig. 3. The dynamic changes of soil salt content (\%) of Robinia pseudoacacia forest.

Table 2

Correlation analysis on precipitation and soil salt content in the same time.

\begin{tabular}{llllll}
\hline & Precipitation & $0-20 \mathrm{~cm}$ & $20-40 \mathrm{~cm}$ & $40-60 \mathrm{~cm}$ & $60-80 \mathrm{~cm}$ \\
\hline Precipitation & 1 & $-0.70^{*}$ & $-0.56^{\mathrm{a}}$ & $-0.78^{* *}$ & $-0.61^{*}$ \\
$0-20 \mathrm{~cm}$ & $-0.70^{*}$ & 1 & $0.84^{* *}$ & $0.87^{* *}$ & $0.83^{* *}$ \\
$20-40 \mathrm{~cm}$ & $-0.56^{\mathrm{a}}$ & $0.84^{* *}$ & 1 & $0.87^{* *}$ & $0.91^{* *}$ \\
$40-60 \mathrm{~cm}$ & $-0.78^{* *}$ & $0.87^{* *}$ & $0.87^{* *}$ & 1 & $0.91^{* *}$ \\
$60-80 \mathrm{~cm}$ & $-0.61^{*}$ & $0.83^{* *}$ & $0.91^{* *}$ & $0.91^{* *}$ & 1 \\
\hline
\end{tabular}

* Significant at the $<0.05$ probability levels.

* Significant at the $<0.01$ probability levels.

a NS-non-significant at $\mathrm{p}<0.05$.

\subsection{Soil salt content of the R. pseudoacacia forest}

No significant differences were shown on soil salt content among different soil layers $(\mathrm{F}=0.36, \mathrm{P}=0.78)$. However, the month had significant effects on soil salt content $(F=4.73, P<0.01)$. Soil salt content increased gradually from November to February, decreased from February to September and then increased in October (Fig. 3). The interaction between soil depth and month was not significant on soil salt content $(\mathrm{F}=0.19, \mathrm{P}=0.99)$. Precipitation was strongly and negatively correlated with soil salt content in different soil layers (except $20-40 \mathrm{~cm}$, Table 2), which indicated precipitation was one of the main determinants on soil salt distribution. Furthermore, soil salt content in the $60-80 \mathrm{~cm}$ was significantly and positively related to the soil salt content in $0-20 \mathrm{~cm}$, in $20-40 \mathrm{~cm}$ and in 40-60 cm (Table 2), which suggested salt in deep soil layer determined surface soil salt content.

\subsection{Soil enzyme activity at different seasons}

There were significant effects on the activities of soil enzymes examined (except catalase) among the different monthes (Table 3 ). With the increase of the month, the activity of polyphenol oxidase increased at first and then decreased, and the maximum values appeared at June $(\mathrm{P}<0.01)$. The activities of alkaline phosphatase, invertase, protease and urease increased with the month 
Table 3

Two-way ANOVA analyses of effects of season and soil depth and their interaction on soil enzyme activity of Robinia pseudoacacia forest.

\begin{tabular}{|c|c|c|c|c|c|c|}
\hline \multirow[b]{2}{*}{ Enzyme } & \multicolumn{2}{|l|}{ Season } & \multicolumn{2}{|c|}{ Soil depth } & \multicolumn{2}{|c|}{ Season $\times$ Soil depth } \\
\hline & F value & P value & F value & P value & F value & P value \\
\hline Polyphenol oxidase & 195.56 & $<0.01$ & 2.85 & 0.11 & 3.52 & $<0.05$ \\
\hline Catalase & 1.32 & 0.30 & 1.60 & 0.70 & 0.07 & 0.98 \\
\hline Alkaline phosphatase & 159.19 & $<0.01$ & 62.03 & $<0.01$ & 9.42 & $<0.01$ \\
\hline Invertase & 94.96 & $<0.01$ & 136.28 & $<0.01$ & 5.12 & $<0.05$ \\
\hline Protease & 9.87 & $<0.01$ & 5.43 & $<0.05$ & 2.56 & 0.09 \\
\hline Urease & 386.78 & $<0.01$ & 306.75 & $<0.01$ & 80.86 & $<0.01$ \\
\hline
\end{tabular}
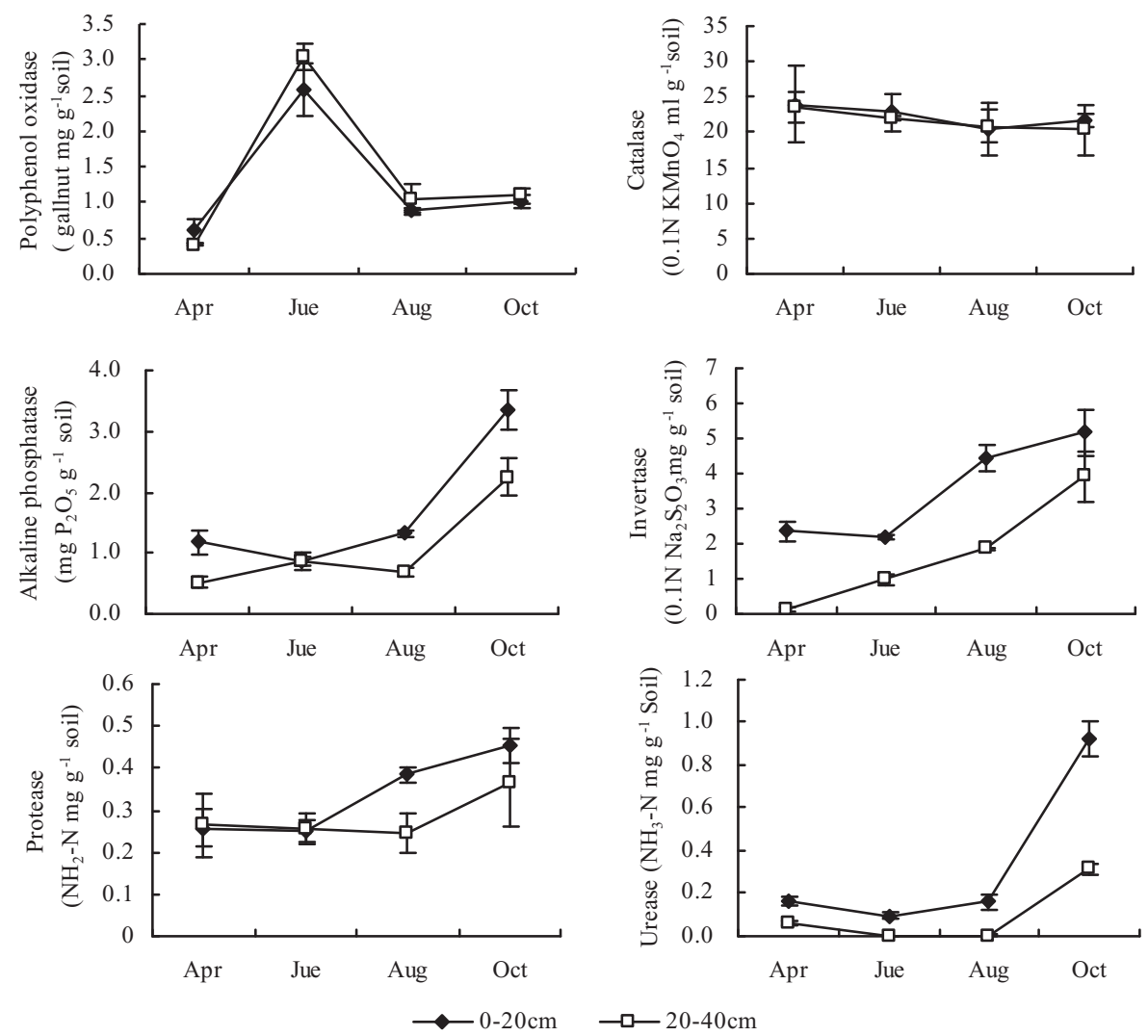

Fig. 4. The soil enzyme activities at different seasons of different soil layers.

Table 4

Two-way ANOVA analyses of effects of season and soil depth and their interaction on soil nutrient of Robinia pseudoacacia forest.

\begin{tabular}{|c|c|c|c|c|c|c|}
\hline \multirow[b]{2}{*}{ Soil nutrient } & \multicolumn{2}{|l|}{ Season } & \multicolumn{2}{|c|}{ Soil depth } & \multicolumn{2}{|c|}{ Season $\times$ Soil depth } \\
\hline & F value & P value & F value & P value & F value & P value \\
\hline Soil or & 66.37 & $<0.01$ & 91.30 & $<0.01$ & 6.38 & $<0.01$ \\
\hline Hydrolysis nitrogen & 220.24 & $<0.01$ & 919.50 & $<0.01$ & 84.81 & $<0.01$ \\
\hline Available potassium & 5.30 & $<0.05$ & 41.20 & $<0.01$ & 0.94 & 0.44 \\
\hline Available phosphorus & 1252.11 & $<0.01$ & 1.12 & 0.35 & 6.68 & $<0.01$ \\
\hline
\end{tabular}

(Fig. 4). Soil depth didn't show significant effects on the activities of polyphenol oxidase and catalase, whereas it had significant effects on the other soil enzymes (Table 3). The activities of acid phosphatase, invertase, protease and urease were higher in the $0-20 \mathrm{~cm}$ than in the $20-40 \mathrm{~cm}$ soil layer.

\subsection{Soil nutrients in different seasons}

Month showed significant effects on all soil nutrient indexes (Table 4). As month increased, soil organic matter, hydrolysis nitrogen and available potassium increased obviously (Fig. 5). Available phosphorus increased at first and then decreased, and reached the maximum values at August $(\mathrm{P}<0.01)$. Soil hydrolysis nitrogen and available potassium showed significant differences between soil layers (Table 4), and they had higher values in the $0-20 \mathrm{~cm}$ than in the $20-40 \mathrm{~cm}$ soil layer. However, there were no significant effects of soil depth on available phosphorus.

\section{Discussion}

Studying the dynamic process of water and salinity change is crucial to the understanding of vegetation distribution and growth in the wetlands (Glaeser et al., 2016; Lin et al., 2016). Soil water content influences both the nutrient uptake by the plants as well as biotic and abiotic processes in the soil (Tullus et al., 2010; Mettrop et al., 2015; Edwards, 2015). In this paper, we discovered that precipitation had significant effects on soil water content, which agreed with the finding from Al-Taai et al. (2014) and Lay et al. (2008). Soil salinity also is one of the important determining factors on plant growth in the coastal region (Dunton et al., 2001; Yan et al., 2016). With the increase of precipitation, we found soil salt content decreased in this paper. Dunton et al. (2001) and Lin et al. (2016) also found the similar results in an estuarine marsh. Moreover, 

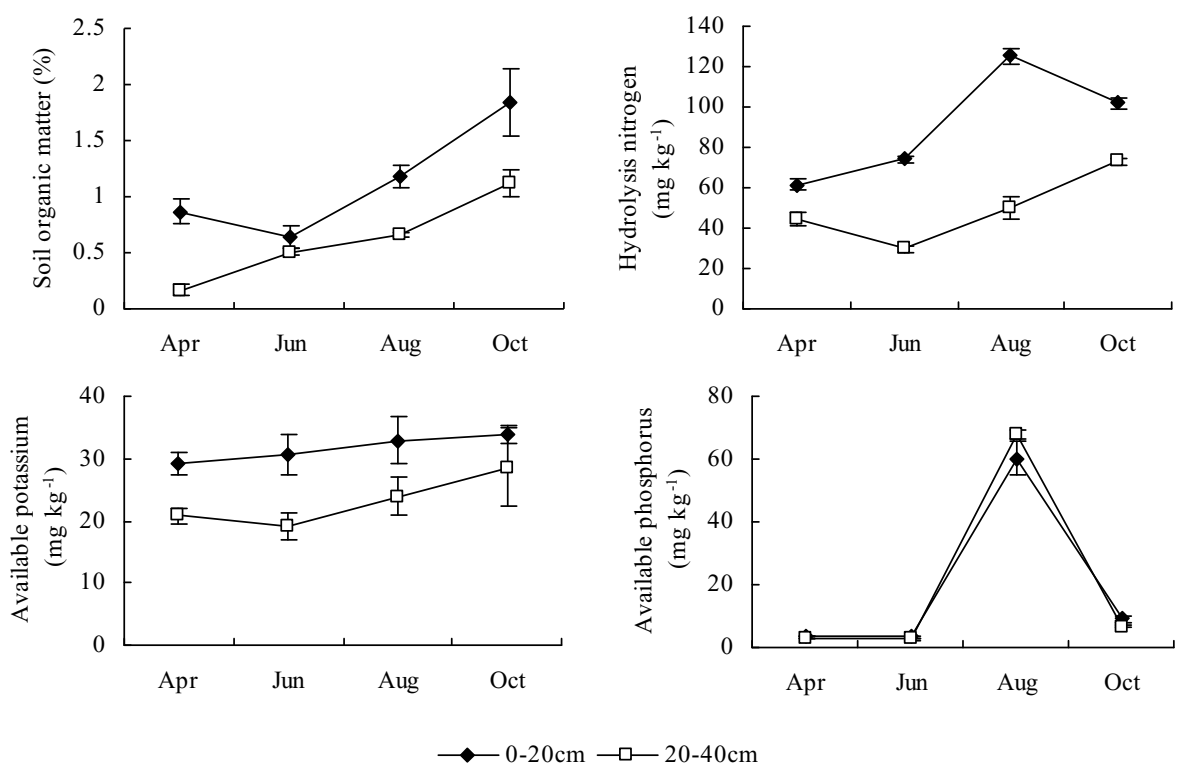

Fig. 5. The soil nutrients at different seasons of different soil layers.

Dunton et al. (2001) thought precipitation events in arid environments may be considered a major physical disturbance that can result in large changes in vegetation composition over a relatively short period (Dunton et al., 2001). In this study area, precipitation season from April to October was consistent with the growth of $R$. pseudoacacia forest. Therefore, precipitation was one of the critical factors of $R$. pseudoacacia forest growth in the Yellow River Delta region.

Soil enzyme activities integrate information both about microbial status and soil physico-chemical conditions (Aon and Colaneri, 2001). Many soil factors (e.g. temperature and soil moisture levels) could change correspondent with seasons, which affect microbial metabolism and production of soil enzymes (Kang and Freeman, 1999). The increase of soil moisture (Baldrian et al., 2013; ÁBear et al., 2014) and temperature (Kang and Freeman, 1999; Fenner et al., 2005; ÁBear et al., 2014) enhances soil enzyme activities. Therefore, the significant increase of polyphenol oxidase activity from April to June was related to the increase of soil water content and temperature. However, the activities of alkaline phosphatase, invertase, protease and urease didn't rise significantly during the same time. ÁBear et al. (2014) thought elevated temperature alone couldn't compensate for the negative effect of drying. Moreover, soil salt content that inhibits soil enzyme activities (Saviozzi et al., 2011; Pan et al., 2013) was higher during this time, too. Hence, soil drought and salinity perhaps were the important limiting factors on soil enzyme activities. Polyphenol oxidase activity dropped abruptly in August, which was related to low oxygen diffusion into soil because of the high precipitation in this month (Kang and Freeman, 1999). Soil hydrolytic enzyme activities (alkaline phosphatase, invertase, protease and urease) increased in August, whereas their maximum values appeared in October. Niu et al. (2012) found rhizosphere ventilation could improve the soil enzyme activity of the potted tomato. The decrease of polyphenol oxidase activity would allow phenolic compounds to accumulate. Phenolics could inhibit the activity of other hydrolase enzymes which are not oxygen limited (Freeman et al., 2001). Consequently, the increase of hydrolytic enzyme activities in October was due to the decrease of soil water content. The hydrolase enzyme activities in this study decreased with depth, which was coincide with Luo et al. (1998) and Bell and Henry (2011). Luo et al. (1998) thought the decrease was related with the decrease of microbial community size.
The changes of soil nutrients are strongly related with plants and abiotic environments (Ladwig et al., 2015). Following the onset of rainfall season, $R$. pseudoacacia grew rapidly. A lot of labile compounds would be exuded through roots and residue of plants (Geisseler et al., 2011), which led to the increase of soil organic matter (Ladwig et al., 2015). Therefore, the increase of soil organic matter in this paper was correlated with the growth of $R$. pseudoacacia. Moreover, plants play an important role on soil microbial community (Chen et al., 2015; Liang et al., 2015). These labile compounds from plants could stimulate soil microbial and enzyme activity (Duan et al., 2015; Xiao et al., 2015). Likewise, increases in soil enzyme activities accelerated the decomposition of organic matter. We also found hydrolytic enzyme, organic matter content and hydrolysis nitrogen increased synchronously. Long droughts can trap nutrients in soil organic matter or on carbonate (Ippolito et al., 2010). However, precipitation could increase nutrient availability in the soil due to high soil water content (Yahdjian and Sala, 2010). Consequently, the increase of soil water content was another reason for the increase of hydrolysis nitrogen, available potassium and available phosphorus. The decrease of available phosphorus in October was perhaps related to the decrease of root growth of $R$. pseudoacacia or the limitation of the accumulated phenolics. In this paper, soil nutrient decreased with the increase of soil depth. High nutrient availability made fine roots concentrate in the soil surface layer (Ugawa et al., 2010), which would impact enzyme activities and microorganism distribution pattern in the soil.

Precipitation is a determining factor on the dynamic process of soil water and salt in the Yellow River Delta. The precipitation induced change on soil drought, salinity and waterlogging showed significant effects on $R$. pseudoacacia growth, soil microbial community size and soil enzyme activities. The impact of precipitation on $R$. pseudoacacia growth, soil microbial community size and soil enzyme activities might be a critical mechanism on clarifying the productivity decline of $R$. pseudoacacia forest in the coastal salinealkali soil of this region. However, according to the meteorological forecast of the global climate, the annual precipitation pattern will change. Consequently, we need to pay more attention to the change of precipitation pattern and adopt indispensable measures of water conservancy and stand regeneration in order to ensure the sustainable ecological function of $R$. pseudoacacia forest in the Yellow River Delta. 


\section{Acknowledgments}

This study was jointly supported by the National Natural Science Foundation of China (30950016), the Agricultural Science and Technology Achievements Transformation Fund Project of China (2011GB2C600024), Shandong Science and Technology Development Plan (2015GNC111026), Shuangchuang Talent Plan of Jiangsu Province and Jiangsu Autonomous Innovation Fund of Agricultural Science \& Technology [CX(15)1005].

\section{References}

ÁBear, A., Jones, T.H., Kandeler, E., Boddy, L., 2014. Interactive effects of temperature and soil moisture on fungal-mediated wood decomposition and extracellular enzyme activity. Soil Biol. Biochem. 70, 151-158.

Acosta-Martinez, V., Moore-Kucera, J., Cotton, J., Gardner, T., Wester, D., 2011. Soil enzyme activities during the 2011 Texas record drought/heatwave and implications to biogeochemical cycling and organic matter dynamics. Appl. Soil Ecol. 75, 43-51.

Al-Taai, O.T., Ahmed, M.M., Jawad, T.K., 2014. Influence of rainfall on soil water content in Iraq. Int. J. Agric. Innov. Res. 3, 618-627.

Aon, M.A., Colaneri, A.C., 2001. II: Temporal and spatial evolution of enzymatic activities and physico-chemical properties in an agricultural soil. Appl. Soil Ecol. 18, 255-270

Baldrian, P., Snajdr, J., Merhautová, V., Dobiášová, P., Cajthaml, T., Valášková, V., 2013. Responses of the extracellular enzyme activities in hardwood forest to soil temperature and seasonality and the potential effects of climate change. Soil Biol. Biochem. 56, 60-68.

Bell, T.H., Henry, H.A.L., 2011. Fine scale variability in soil extracellular enzyme activity is insensitive to rain events and temperature in a mesic system. Pedobiologia 54, 141-146.

Burke, D.J., Weintraub, M.N., Hewins, C.R., Kalisz, S., 2011. Relationship between soil enzyme activities: nutrient cycling and soil fungal communities in a northern hardwood forest. Soil Biol. Biochem. 43, 795-803.

Chen, Y., Wen, Y., Tang, Z., Huang, J., Zhou, Q., Vymazal, J., 2015. Effects of plant biomass on bacterial community structure inconstructed wetlands used for tertiary wastewater treatment. Ecol. Eng. 84, 38-45.

Cui, B., Yang, Q., Zhang, K., Zhao, X., You, Z., 2010. Responses of saltcedar (Tamarix chinensis) to water table depth and soil salinity in the Yellow River Delta, China. Plant Ecol. 209, 279-290.

Duan, B., Zhang, Y., Xu, G., Chen, J., Paquette, A., Peng, S., 2015. Long-term responses of plant growth: soil microbial communities and soil enzyme activities to elevated $\mathrm{CO}_{2}$ and neighbouring plants. Agric. For. Meteorol. 213, 91-101.

Dunton, K.H., Hardegree, B., Whitledge, T.E., 2001. Response of estuarine marsh vegetation to interannual variations in precipitation. Estuaries 24, 851-861.

Edwards, K.R., 2015. Effect of nutrient additions and site hydrology on belowground production and root nutrient contents in two wet grasslands. Ecol. Eng. 84, 325-335.

Fenner, N., Freeman, C., Reynolds, B., 2005. Observations of a seasonally shifting thermal optimum in peatland carbon-cycling processes; implications for the global carbon cycle and soil enzyme methodologies. Soil Biol. Biochem. 37 1814-1821.

Freeman, C., Ostle, N., Kang, H., 2001. An enzymic ‘latch' on a global carbon store. Nature 409, 149.

García-Ruiz, R., Ochoa, V., Hinojosa, M.B., Carreira, J.A., 2008. Suitability of enzyme activities for the monitoring of soil quality improvement in organic agricultural systems. Soil Biol. Biochem. 40, 2137-2145.

Geisseler, D., Horwath, W.R., Scow, K.M., 2011. Soil moisture and plant residue addition interact in their effect on extracellular enzyme activity. Pedobiologia $54,71-78$

Glaeser, L.C., Vitt, D.H., Ebbs, S., 2016. Responses of the wetland grass, Beckmannia syzigachne, to salinity and soil wetness: consequences for wetland reclamation in the oil sands area of Alberta, Canada. Ecol. Eng. 86, 24-30.

Hendriksen, N.B., Creamer, R.E., Stone, D., Winding, A., 2015. Soil exo-enzyme activities across Europe-the influence of climate, land-use and soil properties. Appl. Soil Ecol., http://dx.doi.org/10.1016/j.apsoil.2015.08.012.

Henry, H.A.L., 2013. Reprint of soil extracellular enzyme dynamics in a changing climate. Soil Biol. Biochem. 56, 53-59.

Institute of Soil Science, Chinese Academy of Sciences (ISSCAS), 1978. Physical and Chemical Analysis Methods of Soils. Shanghai Science Technology Press, Shanghai (in Chinese).

Ippolito, J.A., Blecker, S.W., Freeman, C.L., McCulley, R.L., Blair, J.M., Kelly, E.F., 2010. Phosphorus biogeochemistry across a precipitation gradient in grasslands of central North America. J. Arid Environ. 74, 954-961.
Kang, H., Freeman, C., 1999. Phosphatase and arylsulphatase activities in wetland soils: annual variation and controlling factors. Soil Biol. Biochem. 31, 449-454. Ladwig, L.M., Sinsabaugh, R.L., Collins, S.L., Thomey, M.L., 2015. Soil enzyme responses to varying rainfall regimes in Chihuahuan Desert soils. Ecosphere 6, $1-10$.

Lay, F., Scarpati, O., Capriolo, A., 2008. Precipitation variability and soil water content in Pampean Flatlands (Argentina). Geofís. Int. 47, 341-354.

Liang, Y., He, X., Chen, C., Feng, S., Liu, L., Chen, X., Zhao, Z., Su, Y., 2015. Influence of plant communities and soil properties during natural vegetation restoration on arbuscular mycorrhizal fungal communities in a karst region. Ecol. Eng. 82, 57-65.

Lin, Q., Ishikawa, T., Akoh, R., Yang, F., Zhang, S., 2016. Soil salinity reduction by river water irrigation in a reed field: a case study in Shuangtai Estuary Wetland, Northeast China. Ecol. Eng. 89, 32-39.

Liu, Q.S., Liu, G.H., Yao, L., 2008. Detection of Robinia Pseudoacacia planted forest canopy health using landsat $\mathrm{ETM}^{+}$image data. Remote Sens. Technol. Appl. 23, $142-146$.

Luo, J., Tillman, R.W., White, R.E., Ball, P.R., 1998. Variation in denitrification activity with soil depth under pasture. Soil Biol. Biochem. 30, 897-903.

Marx, M., Wood, M., Jarvis, S.C., 2001. A microplate fluorimetric assay for the study of enzyme diversity in soils. Soil Biol. Biochem. 33, 1633-1640.

Mettrop, I.S., Rutte, M.D., Kooijman, A.M., Lamers, L.P.M., 2015. The ecological effects of water level fluctuation and phosphateenrichment in mesotrophic peatlands are strongly mediated bysoil chemistry. Ecol. Eng. 85, 226-236.

Morrissey, E.M., Gillespie, J.L., Morina, J., Franklin, R.B., 2014. Salinity affects microbial activity and soil organic matter content in tidal wetlands. Glob. Change Biol. 20, 1351-1362.

Munson, S.M., Benton, T.J., Lauenroth, W.K., Burke, I.C., 2010. Soil carbon flux following pulse precipitation events in the shortgrass steppe. Ecol. Restor. 25, 205-211.

Niu, W., Zang, X., Jia, Z., Shao, H., 2012. Effects of rhizosphere ventilation on soil enzyme activities of potted tomato under different soil water stress. Clean-Soil Air Water 40, 225-232.

Pan, C., Liu, C., Zhao, H., Wang, Y., 2013. Changes of soil physico-chemical properties and enzyme activities in relation to grassland salinization. Eur. J. Soil Biol. 55, 13-19.

Saviozzi, A., Cardelli, R., Di Puccio, R., 2011. Impact of salinity on soil biological activities: a laboratory experiment. Commun. Soil Sci. Plant Anal. 42, 358-367.

Sun, Q.X., Zhang, J.F., Makeschin, F., 2006. Evaluation of soil chemical properties and enzymes activity under different land use systems. J. Soil Water Conserv. 20, 98-101, 159-159.

Toktar, M., Papa, G.L., Kozybayeva, F.E., Dazzi, C., 2016. Ecological restoration in contaminated soils of Kokdzhon phosphate mining area (Zhambyl region, Kazakhstan). Ecol. Eng. 86, 1-4.

Tullus, A., Kanal, A., Soo, T., Tullus, H., 2010. The impact of available water content in previous agricultural soils on tree growth and nutritional status in young hybrid aspen plantations in Estonia. Plant Soil 333, 129-145.

Ugawa, S., Miura, S., Iwamoto, K., Kaneko, S., Fukuda, K., 2010. Vertical patterns of fine root biomass, morphology and nitrogen concentration in a subalpine fir-wave forest. Plant Soil 335, 469-478.

Worth, H.G., 1985. A Comparison of the measurement of sodium and potassium by flame photometry and ion-selective electrode. Ann. Clin. Biochem. 22, 343-350.

Xia, J.B., Lu, Z.H., Gao, P., Xu, J.W., Li, C.R., 2009. Soil water storage ability of different vegetation types in lowlands of the Yellow River Delta. J. Soil Water Conserv. 23, 72-75, 95-95.

Xiao, Y., Huang, Z., Lu, X., 2015. Changes of soil labile organic carbon fractions and their relation to soil microbial characteristics in four typical wetlands of Sanjiang Plain, Northeast China. Ecol. Eng. 82, 381-389.

Yahdjian, L., Sala, O.E., 2010. Size of precipitation pulses controls nitrogen transformation and losses in an arid Patagonian ecosystem. Ecosystems 13 , $575-585$.

Yan, K., Xu, H., Zhao, S., Shan, J., Chen, X., 2016. Saline soil desalination by honeysuckle (Lonicera japonica Thunb.) depends on salt resistance mechanism. Ecol. Eng. 88, 226-231.

Yu, J., Wang, X., Ning, K., Li, Y., Wu, H., Fu, Y., Zhou, D., Guan, B., Lin, Q., 2012. Effects of salinity and water depth on germination of Phragmites australis in coastal wetland of the Yellow River Delta. Clean -Soil Air Water 40, 1154-1158.

Zhang, J.F., Xing, S.J., 2009. Research on soil degradation of Robinia pseudoacacia plantation under environmental stress. Chin. J. Soil Sci. 40, 1086-1091.

Zornozao, R., Guerrero, C., Mataix-Solera, J., Arcenegui, V., García-Orenes, F. Mataix-Beneyto, J., 2006. Assessing air-drying and rewetting pre-treatment effect on some soil enzyme activities under Mediterranean conditions. Soil Biol. Biochem. 38, 2125-2134. 